\title{
IMPLEMENTASI PERMAINAN KADO UNTUK MENINGKATKAN HASIL BELAJAR SISWA KELAS VI SDN PAGENTAN O1 SINGOSARI PADA POKOK BAHASAN PECAHAN
}

\author{
Iriyanto. Ratna Kartika Irawati \\ Sekolah Dasar Negeri Pagentan 01 Singosari \\ e-mail: iriyantoyuli@gmail.com, ratna.kartika24@gmail.com
}

\begin{abstract}
ABSTRAK
Salah satu pokok bahasan matematika yang dibelajarkan pada siswa sekolah dasar adalah pecahan. Konsep-konsep pecahan merupakan konsep yang abstrak dan deduktif. Hal ini menyebabkan siswa mengalami kesulitan dalam mengerjakan soal-soal pecahan. Kesulitan siswa ini juga ditunjukkan dengan hasil ulangan pecahan yang belum mencapai KKM. Salah satu solusi yang dapat ditawarkan untuk mengatasi masalah tersebut adalah dengan pengembangan media pembelajaran KADO (Kartu Domino). Penelitian ini bertujuan untuk mengetahui penggunaan KADO melalui kerja kelompok dalam meningkatkan keaktifan dan hasil belajar dengan pokok bahasan pecahan pada siswa kelas VI A SDN Pagentan 01 Singosari. Penelitian ini menggunakan rancangan penelitian deskriptif kualitatif dan jenis penelitiannya adalah Penelitian Tindakan Kelas (PTK) dengan tiga fase yaitu perencanaan, tindakan dan observasi serta refleksi. Subjek penelitian adalah siswa Kelas VI A SDN Pagentan 01 Singosari yang berjumlah 34 siswa. Instrumen penelitian berupa media pembelajaran KADO dan tes formatif pecahan. Teknik analisis data menggunakan hasil tes dan observasi. Hasil penelitian menunjukkan bahwa media pembelajaran KADO dapat meningkatkan keaktifan dan hasil belajar siswa pada pokok bahasan pecahan.
\end{abstract}

Kata Kunci : Permainan Kado, Pecahan, Hasil Belajar

\section{PENDAHULUAN}

Matematika merupakan salah satu mata pelajaran wajib yang diberikan kepada siswa di sekolah dasar. Matematika di sekolah dasar meliputi konsep-konsep seperti bilangan dan operasinya, pecahan, gometri, pengukuran dan pengolahan data. Menurut Lentera (2011), pembelajaran matematika adalah proses pemberian pengalaman belajar kepada siswa melalui serangkaian kegiatan yang terencana sehingga siswa memperoleh kompetensi tentang bahan matematika yang dipelajari. Tujuan pembelajaran matematika adalah untuk menumbuhkan dan mengembangkan ketrampilan berhitung dalam kehidupan sehari-hari, menumbuhkan kemampuan siswa, mengembangkan pengetahuan dasar matematika serta menumbuhkan sikap logis, kritis, cermat, kreatif dan disiplin (Depdikbud, 1999).

Menurut De Walle (2008), prinsip belajar matematika berdasarkan NCTM (National Council of Teachers of Mathematics, AS) yaitu siswa belajar matematika dengan pemahaman, secara aktif membangun pengetahuan baru dari pengetahuan dan pengalaman yang sudah dimiliki oleh siswa. Dengan demikian, penanaman konsep matematika pada siswa sekolah dasar harus benar dan tepat agar dapat digunakan pada konsep-konsep matematika tingkat lanjut 
Salah satu pokok bahasan matematika yang dibelajarkan pada siswa sekolah dasar adalah pecahan. Pecahan merupakan bilangan rasional yang melambangkan bilangan pecah (Hestuaji, Suwarto, dan Riyadi, 2010). Setiap pecahan mempunyai nilai berbeda-beda dan siswa dituntut dapat membandingkan nilai antara pecahan satu dengan pecahan yang lainnya. Materi pecahan di kelas 6 merupakan lanjutan dari materi pecahan di kelas 4 dan 5. Pada materi pecahan kelas 6, siswa belajar tentang menyederhanakan dan mengurutkan pecahan; mengubah bentuk pecahan; menentukan nilai pecahan dari suatu bilangan atau kuantitas tertentu; melakukan operasi hitung bilangan pecahan serta memecahkan masalah perbandingan dan skala.

Konsep-konsep matematika, khususnya dalam materi pecahan merupakan konsep yang abstrak dan deduktif (Duski, Kumaidi, dan Suryanto, 2014). Hal ini menyebabkan siswa mengalami kesulitan dalam mengerjakan soal-soal pecahan. Berdasarkan Pusat Pengembangan Kurikulum dan Sarana Pendidikan Badan Penelitian dan Pengembangan (Depdikbud, 1999) menyebutkan bahwa pecahan merupakan salah satu topik yang sulit dipahami oleh siswa. Nugraheni, dkk (2010) menyebutkan bahwa pokok bahasan pecahan selalu menjadi tantangan yang cukup berat bagi siswa. Pada pembelajaran pecahan, siswa harus dilibatkan aktif dalam proses pembelajaran sehingga siswa dapat memahami konsep pecahan dengan baik.

Berdasarkan hasil survei dan wawancara di SD Pagentan 01 Singosari, siswa kelas VI A mengalami kesulitan dalam menyelesaikan soalsoal pecahan. Siswa kurang memahami maksud dari isi soal yang diberikan dan juga belum mampu dalam berpikir abstrak pada konsep-konsep pecahan. Kesulitan siswa ini juga ditunjukkan dengan hasil ulangan pecahan yang hanya mempunyai rata-rata sebesar 63. Hal ini berarti hanya sedikit siswa yang mencapai KKM (KKM 275). Rata-rata nilai ulangan pecahan yang belum mencapai KKM menunjukkan bahwa pemahaman konsep siswa masih belum mendalam.

Salah satu solusi yang dapat ditawarkan untuk mengatasi masalah tersebut adalah dengan pengembangan media pembelajaran yang menarik. Rosyada (2010) mengatakan manfaat media pembelajaran diantaranya adalah sebagai sumber belajar, menambah perbendaharaan kata bagi siswa, mengatasi batas ruang, waktu dan indra, membantu siswa berkomunikasi dengan yang lain. Hal ini membuat siswa bosan menggunakan media dan tidak membantu meningkatkan pemahaman siswa konsep pecahan. Oleh sebab itu, perlu dikembangkan media pembelajaran yang menarik untuk membantu siswa memahami konsep pecahan.

KADO (Kartu Domino) dapat digunakan sebagai media pembelajaran pecahan yang menarik bagi siswa. Hal ini bertujuan untuk menarik minat siswa dalam mempelajari pecahan sehingga diharapkan dapat meningkatkan pemahaman konsep siswa. Kartu domino dapat juga digunakan untuk menghafal fakta dasar penjumlahan, pengurangan, perkalian dan pembagian serta digunakan untuk menghafal bangun-bangun geometri (Darhim, 2001). Kartu domino digunakan secara berkelompok. Dengan demikian, kartu domino juga dapat meningkatkan interaksi satu siswa dengan yang lainnya sehingga dapat menumbuhkan interaksi sosial.

Implementasi KADO dalam pembelajaran pecahan bertujuan untuk membantu siswa dalam memahami konsep pecahan. Selain itu juga sebagai ajang berlatih menyelesaikan soal-soal pecahan serta untuk menarik minat siswa dalam mempelajari pecahan. Penggunaan KADO juga diharapkan dapat 
meningkatkan interaksi sosial sebab penggunaan KADO dilaksanakan secara berkelompok. Pengembangan media KADO difokuskan pada konsep pecahan senilai dalam berbagai bentuk, yaitu pecahan biasa, decimal dan persentase, Dengan demikian, penggunaan KADO diharapkan dapat meningkatkan hasil belajar siswa pada pokok bahasan pecahan.

\section{METODE PENELITIAN}

Penelitian ini menggunakan metode Penelitian Tindakan Kelas (PTK). Mukhlis (2000: 5) PTK adalah suatu bentuk kajian yang bersifat sistematis reflektif oleh pelaku tindakan untuk memperbaiki kondisi pembelajaran yang dilakukan. Tujuan utama dari PTK adalah untuk memperbaiki praktek pembelajaran secara berkesinambungan; meningkatkan pemahaman siswa tentang konsep pecahan; serta meningkatkan nilai matematika siswa. Penelitian ini menggunakan dua siklus. Setiap siklus meliputi planning (rencana), action (tindakan), observation (pengamatan), dan reflection (refleksi).

Langkah pada siklus berikutnya adalah perncanaan yang sudah direvisi, tindakan, pengamatan, dan refleksi. Sebelum masuk pada siklus 1 dilakukan tindakan pendahuluan yang berupa identifikasi permasalahan. Siklus dari tahap-tahap penelitian tindakan kelas dapat dilihat pada gambar berikut.

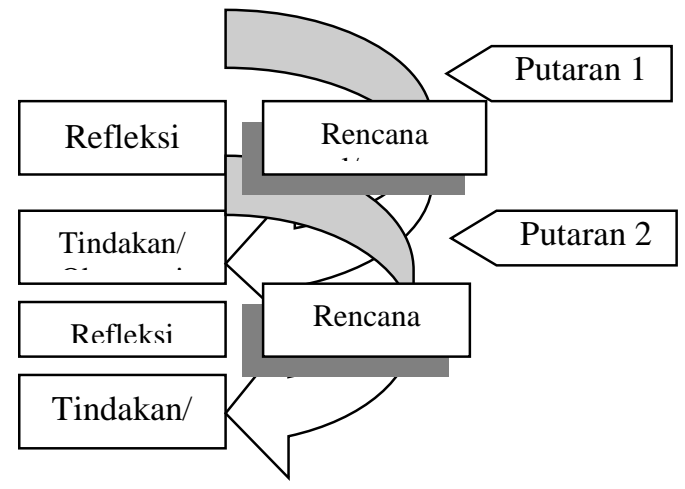

Gambar 1. Alur Penelitian Tindakan Kelas
Subyek dalam penelitian ini adalah siswa kelas VI SD Negeri Pagentan 1 Singosari yang berjumlah 34 orang. Penelitian dilakukan di kelas VI A SD Negeri Pagentan 01 Singosari dan dilaksanakan pada bulan Januari-Februari 2015.

Pada penelitian ini, peneliti bertindak sebagai guru yang memberikan pembelajaran pecahan dengan media KADO. Prosedur penelitian tindakan kelas ini dimulai fase perencanaan dengan menyusun silabus dan RPP dengan pokok bahasan pecahan. Selain itu juga mengembangkan media KADO yang akan digunakan oleh siswa. Peneliti mengembangkan sendiri media KADO yang digunakan. Pertama, menentukan pecahan yang akan digunakan dan dikembangkan dalam 36 kartu. Kemudian membuat soal tes formatif pecahan yang diberikan pada siswa setelah pembelajaran diberikan.

Fase selanjutnya yaitu tindakan dan observasi. Fase observasi dapat dilakukan dengan mengukur kemampuan awal siswa melalui tes awal, sedangkan fase tindakan berupa pelaksanaan kegiatan pembelajaran KADO pada pecahan sesuai dengan silabus dan RPP yang telah disusun. Siswa dibagi menjadi 6 kelompok dan masing-masing kelompok terdiri atas 5-6 siswa. KADO dibagikan kepada siswa. Masing-masing 6-7 kartu dan mulai memainkannya. Siswa yang kartunya habis terlebih dahulu, maka dapat dikatakan sebagai pemenang. Tetapi, kartu siswa yang tidak habis maka dapat dikatakan siswa tersebut belum memahami konsep pecahan.

Fase refleksi dilakukan dengan melihat hasil penggunaan media KADO melalui kerja kelompok dalam meningkatkan hasil ulangan pecahan. Apabila nilai ulangan siswa belum meningkat secara signifikan dari kemampuan awal, maka perlu dilakukan siklus kedua dengan memperbaiki proses pembelajaran siklus pertama. Bagi siswa 
yang belum memahami konsep pecahan dengan baik maka dilakukan pengayaan untuk siswa tersebut.

Instrumen yang digunakan ada dua yaitu instrumen perlakukan berupa silabus, RPP, dan media pembelajaran KADO. Sedangkan instrumen pengukuran berupa soal tes pecahan yang diberikan setelah pembelajaran pecahan selesai. Selain itu juga digunakan dokumentasi pada saat pembelajaran berlangsung. Teknik pengumpulan data yang digunakan dalam penelitian ini yaitu lembar observasi dan catatan lapangan, dokumen, tes pecahan dan dokumentasi.

Analisa data yang digunakan adalah analisa data deskriptif kuantitatif yang diperoleh dari :
1. Hasil observasi yang memuat catatan tentang kegiatan pembelajaran

2. Hasil post test pada setiap pertemuan setelah menggunakan media pembelajaran KADO

Rumus yang digunakan dalam mengolah data dan menganalisis data antara lain :

a. $\quad$ Rata-rata $($ Mean $=M)$

Rumus:

$$
M=\frac{\text { Jumlah Nilai Siswa }}{\text { JumlahSiswa }}
$$

Rumus tersebut digunakan untuk menghitung perkembangan dan peningkatan proses belajar siswa, jika dibandingkan antara siklus yang satu dengan siklus yang lainnya.

b. Mencari ketuntasan belajar klasikal Rumus :

$$
\begin{aligned}
& \text { Ketuntasan belajar klasikal } \\
& =\frac{\text { Jumlah siswa tuntas }}{\text { Iumlah seluruh siswa }} \times 100 \%
\end{aligned}
$$

Untuk menentukan seorang siswa tergolong tuntas atau tidak tuntas sebagai tolak ukur adalah KKM (Kriteria Ketuntasan Minimal) yang telah ditetapkan oleh guru. KKM tersebut sebesar 75 dengan ketuntasan klasikal minimal sebesar $85 \%$.

\section{HASIL DAN PEMBAHASAN}

Peneliti yang bertindak sebagai guru menggunakan hasil tes formatif materi pecahan tiap pertemuan. Pengembangan media oleh guru dapat dilakukan dengan baik. Berikut langkahlangkah pengembangan media KADO yang dilakukan oleh guru.

1. Menentukan bentuk pecahan yang akan digunakan. Dalam penelitian ini digunakan 8 pecahan, yaitu $\frac{1}{2} ; \frac{1}{3} ; \frac{1}{4} ; \frac{2}{3} ; \frac{2}{5} ; \frac{3}{4} ; \frac{3}{5} ;$ dan $\frac{4}{5}$

2. Mengembangkan KADO (Kartu Domino) dari pecahan-pecahan yang telah ditentukan. Pecahan ditulis berpasangan sehingga menjadi 36 kartu. Pecahan ditulis dalam pecahan biasa, desimal dan persentase.

Contoh :

\begin{tabular}{|l|l|}
\hline $1 / 2$ & 0,5 \\
\hline
\end{tabular}

\begin{tabular}{|l|l|}
\hline $1 / 3$ & $25 \%$ \\
\hline
\end{tabular}

3. Membuat KADO yang berukuran 3 $\mathrm{cm}$ x $8 \mathrm{~cm}$ dan bertuliskan pecahanpecahan yang telah ditentukan.

Proses pengembangan media KADO dirasa paling sulit pada langkah kedua, yaitu menentukan pecahan yang digunakan dan menyusunnya dalam bentuk pecahan biasa, desimal dan persen pada KADO.

Setelah media KADO dikembangkan, guru melaksanakan kegiatan pembelajaran pada siswa kelas VI A SDN Pagentan 01. Kegiatan pembelajaran pertama sebagai Siklus I diawali dengan kegiatan pendahuluan dan pembentukan kelompok yang beranggotakan 5-6 orang. Guru menjelaskan tentang pecahan biasa, pecahan desimal dan persen. Kemudian guru memberikan satu set KADO pada setiap kelompok. Guru menjelaskan aturan main yang digunakan, yaitu:

1. Pengocokkan KADO, dilakukan pengocokkan kartu terlebih dahulu.

2. Pembagian KADO pada masingmasing kelompok. Untuk kelompok 
yang beranggotakan 6 siswa, maka KADO dibagi menjadi 6 sehingga satu siswa memegang 6 kartu. Siswa yang memegang kartu

\begin{tabular}{|l|l|}
\hline $1 / 2$ & 0,5 \\
\hline
\end{tabular}

diletakkan di atas meja sebagai kartu pembuka. Untuk kelompok yang beranggotakan 5 siswa, setiap siswa memegang 6 kartu, sisa kartu satu digunakan sebagai kartu pembuka.

3. Permainan dimulai searah jarum jam sesuai dengan KADO pembuka. Setiap siswa harus mengeluarkan kartu sesuai dengan nilai pada kartu tiap sisi-sisinya.

4. Apabila ada siswa yang tidak memahami pecahan, maka siswa tersebut tidak bisa mengeluarkan akrtu dan dilompati pada giliran siswa selanjutnya.

5. Siswa yang kartunya telah habis terlebih dahulu, maka dapat dikatakan sebagai pemenang dan memahami konsep pecahan. Bagi siswa yang kartunya tidak habis maka dapat dikatakan belum memahami konsep pecahan dan perlu diberikan pengayaan.

Berikut ini gambar kegiatan siswa saat melaksanakan permainan KADO.

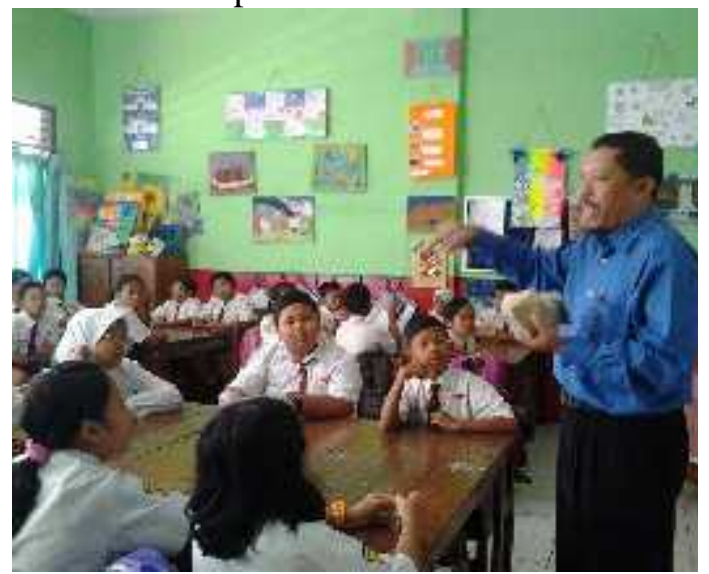

Gambar 2. Guru Menjelaskan Cara Bermain KADO
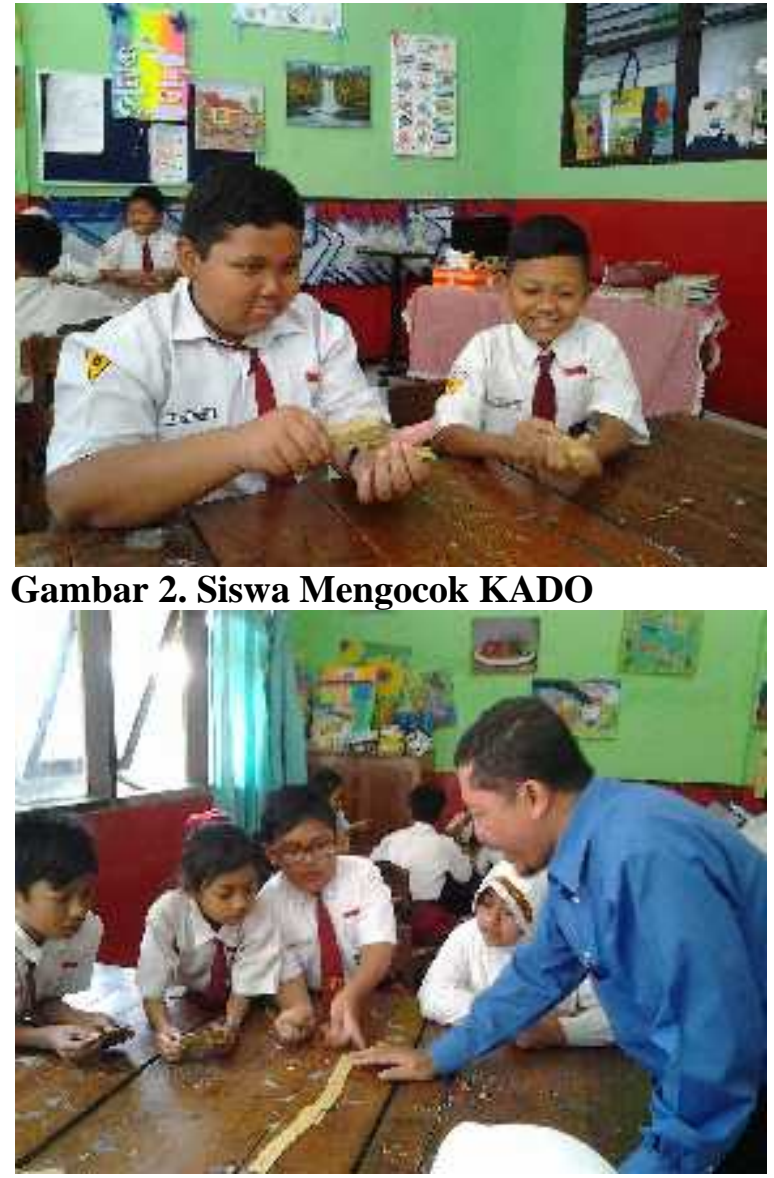

Gambar 3. Guru Membimbing Siswa

Setelah melakukan permainan

KADO, siswa diberikan tes formatif untuk mengetahui pemahaman konsep siswa tentang pecahan. Pembelajaran pada Siklus I tergolong berjalan dengan baik walaupun ada beberapa kendala. Kendala yang dialami adalah ada beberapa siswa yang belum memahami permainan KADO sehingga membuat keributan sendiri. Selain itu, guru kurang memotivasi siswa dalam mengikuti permainan KADO. Kendala-kendala ini perlu diperbaiki pada siklus II.

Pada Siklus II masih membahas tentang konsep pecahan dengan media pembelajaran KADO. Pembelajaran sama dengan Siklus I, hanya saja yang membedakan adalah pada pembagian kelompok dan soal tes formatif. Pembagian kelompok didasarkan pada siswa yang berkemampuan awal tinggi dan rendah. Hal ini bertujuan agar permainan KADO dapat dilakukan 
dengan baik. Soal tes formatif juga dikembangkan lebih baik lagi. Keaktifan siswa dalam Siklus II meningkat dibandingkan dengan keaktifan siswa pada Siklus I

Berikut hasil rekapitulasi keaktifan siswa pada siklus I dan II.

Tabel 1 Rekapitulasi Keaktifan Siswa di Siklus I

\begin{tabular}{lll}
\hline No & Keaktifan Siswa & $\begin{array}{l}\text { Persentase } \\
(\%)\end{array}$ \\
\hline 1. & $\begin{array}{l}\text { Siswa sangat } \\
\text { aktif }\end{array}$ & 17,64 \\
\hline 2. & Siswa aktif & 26,47 \\
\hline 3. & Siswa biasa saja & 35,29 \\
\hline 4. & Siswa pasif & 20,59 \\
\hline
\end{tabular}

Tabel 2. Rekapitulasi Keaktifan Siswa di Siklus II

\begin{tabular}{lll}
\hline No & Keaktifan Siswa & $\begin{array}{l}\text { Persentase } \\
(\%)\end{array}$ \\
\hline 1. & $\begin{array}{l}\text { Siswa sangat } \\
\text { aktif }\end{array}$ & 26,47 \\
\hline 2. & Siswa aktif & 41,17 \\
\hline 3. & Siswa biasa saja & 23,53 \\
\hline 4. & Siswa pasif & 8,82 \\
\hline
\end{tabular}

Berdasarkan Tabel 1 dan 2 dapat diketahui bahwa keaktifan siswa pada pembelajaran dengan media KADO pada materi pecahan mengalami peningkatan. Hal ini menunjukkan bahwa siswa tertarik dengan pembelajaran KADO pada materi pecahan. Siswa merasa senang sebab pembelajaran dapat dilakukan sambil bermain. Dengan demikian dapat membantu siswa dalam memahami konsep pecahan.

Selain dapat meningkatkan keaktifan siswa, pembelajaran pecahan dengan media KADO dapat meningkatkan pemahaman konsep siswa. Pada hasil postes siklus I, hanya 59\% yang mencapai nilai KKM, sehingga diperlukan Siklus II untuk meningkatkan hasil postes siswa. Setelah dilakukan Siklus II, ternyata nilai siswa yang mencapai KKM sebanyak 79\%. Berikut rekapitulasi hasil postes materi pecahan pada Siklus I dan II.

Tabel 3 Rekapitulasi Hasil Postes Siklus I

\begin{tabular}{llll}
\hline No & $\begin{array}{l}\text { Nilai } \\
\text { Siswa }\end{array}$ & $\begin{array}{l}\text { Jumlah } \\
\text { Siswa }\end{array}$ & Siswa (\%) \\
\hline 1. & $\geq 75$ & 20 & 59 \\
\hline 2. & $\leq 75$ & 14 & 41 \\
\hline Jumlah & 34 & 100 \\
\hline
\end{tabular}

Nilai terendah : 40

Nilai tertinggi : 90

Nilai rata-rata : 62,56

Ketuntasan klasikal :

$\frac{20}{34} \times 100 \%=59 \%$

Tabel 4 Rekapitulasi Hasil Postes Siklus II

\begin{tabular}{llll}
\hline No & $\begin{array}{l}\text { Nilai } \\
\text { Siswa }\end{array}$ & $\begin{array}{l}\text { Jumlah } \\
\text { Siswa }\end{array}$ & Siswa $(\%)$ \\
\hline 1. & $\geq 75$ & 29 & 87 \\
\hline 2. & $\leq 75$ & 5 & 13 \\
\hline \multicolumn{2}{l}{ Jumlah } & 34 & 100 \\
\hline
\end{tabular}

Nilai terendah : 50

Nilai tertinggi : 100

Nilai rata-rata : 78,46

Ketuntasan klasikal :

$\frac{29}{34} \times 100 \%=87 \%$

Hasil penguasaan konsep siswa pada materi pecahan menunjukkan peningkatan yang signifikan dari siklus I ke siklus II. Hal ini ditunjukkan dari ketuntasan belajar klasikal yang mengalami peningkatan sebesar 32\% dari pembelajaran siklus I ke siklus II. Pada siklus I, ada 20 anak yang belajar tuntas, sedangkan siklus II ada 29 anak yang belajar tuntas. Peningkatan ini berarti media pembelajaran KADO dapat membantu siswa memahami konsep pecahan dengan baik.

Melalui media KADO, ternyata membawa dampak positif pada proses pembelajaran pecahan. Dengan adanya pembelajaran KADO, siswa dapat berperan aktif dalam proses 
pembelajaran. Selain itu juga pemahaman konsep siswa tentang pecahan menjadi lebih baik. Hasil belajar siswa pada penelitian ini dapat dibandingkan dengan hasil belajar siswa pada metode konvensional. Siswa merasa bosan dan sulit dalam memahami konsep pecaham sehingga berdampak pada hasil belajar siswa yang kurang memuaskan. Oleh sebab itu, media KADO dapat dikembangkan untuk membantu siswa belajar.

\section{KESIMPULAN DAN SARAN}

Berdasarkan hasil penelitian dan pembahasan yang telah dikemukakan, maka dapat disimpulkan bahwa media pembelajaran KADO dapat meningkatkan kualitas proses pembelajaran pecahan sehingga siswa menjadi lebih aktif dalam belajar. Selain itu, media pembelajaran KADO dapat meningkatkan hasil belajar siswa tentang pecahan sehingga pemahaman siswa tentang konsep pecahan dapat meningkat. Oleh sebab itu, media pembelajaran KADO dapat dikembangkan oleh guru untuk meningkatkan proses dan hasil belajar siswa pada mata pelajaran apapun.

\section{DAFTAR PUSTAKA}

Darhim. 2001. Media dan Alat Peraga dalam Pembelajaran Matematika. (online)

(http://staff.uny.ac.id/sites/default/f iles/pengabdian/dr-ali-mustadi$\mathrm{mpd} /$ karya-tulis-ilmiah.pdf diakses 20 September 2014)

De Walle. 2008. Sekolah Dasar dan Menengah Matematika: Pengembangan dan Pengajaran. Jakarta: Erlangga.

Duski, Kumaidi, dan Suryanto. 2014. Pengembangan Tes Diagnostik Kesulitan Belajar Matematika di SD. Jurnal Pendidikan dan Evaluasi Pendidikan. 18(1): 44-56.

Hestuaji,Y., Suwarto, dan Riyadi. 2010. Pengaruh Media Kartu Domino
Terhadap Pemahaman Konsep Pecahan. PGSD FKIP Universitas Sebelas Maret. 3(4): 1-6.

Lentera. 2011. Pembelajaran Matematika di Sekolah Dasar. (online) (http://www.tedcbandung.com/tedc 2011/pdf/mjld0205.pdf diakses tanggal 20 September 2014)

Mukhlis, Abdul. (Ed). 2000. Penelitian Tindakan Kelas. Makalah Panitia Pelatihan Penulisan Karya Ilmiah untuk Guru-guru se-Kabupaten Tuban.

Nugraheni, dkk.2010.Penggunaan Media Kartu Pecahan Untuk Meningkatkan Hasil Belajar Matematika Konsep Pecahan. PGSD FKIP Universitas Sebelas Maret Surakarta.

Payne.2003.Strategi Pembelajaran Matematika di SD dan Karakteristik Anak Didik. (online) (http://mudjiarahardjo.com/artikel/ 174-kemampuan-menulis-gurulemah.html diakses tanggal 20 September 2014)

Rosyada.2010. Permainan Matematika Menggunakan Kartu Domino. (online)( http://www.tedcbandung.com/tedc 2011/pdf/mjld0205.pdf diakses tanggal 20 September 2014) 